\title{
Perilaku Seks Pranikah pada Remaja Kota Juang Bireun
}

\author{
Nurlaely. $\mathrm{HS}^{1}$ \\ Fikarwin Zuska ${ }^{2}$ \\ Achmad Rifai $^{3}$ \\ ${ }^{1)}$ Kebidanan STIKes Payung Negeri Aceh Darussalam \\ ${ }^{2,3}$ Magister Kesehatan Masyarakat Institut Kesehatan Helvetia \\ Email : nurlaely_hs@yahoo.co.id
}

\begin{abstract}
ABSTRAK
Problem yang terjadi di Aceh untuk persoalan pacaran terkait aktifitas seksual semakin meningkat. Tujuan penelitian adalah untuk menganalisis faktor-faktor yang mempengaruhi perilaku seks pranikah pada remaja di Desa Meunasah Gadong Kecamatan Kota Juang Kabupaten Bireuen Tahun 2017. Fokus penelitian ini adalah remaja yang melakukan hubungan seksual (intim) sebelum menikah. Penelitian ini merupakan penelitian kualitatif dengan strategi naratif, dimana informan dalam penelitian ini adalah remaja putri yang melakukan hubungan seksual (intim) yang mengakibatkan kehamilan pranikah berjumlah 2 orang. Pengumpulan data dilakukan dengan wawancara mendalam (in depth-interview). Analisis data menggunakan teknik "on going analysis." Hasil penelitian ini menunjukkan bahwa terjadinya kehamilan pada remaja dipengaruhi oleh adanya tekanan dari pacar, pergaulan bebas, kurang perhatian keluarga, kurang pengetahuan tentang kesehatan reproduksi, kurangnya pengawasan masyarakat umum dan pendidikan agama.

Kata kunci: Seks Pranikah, Remaja
\end{abstract}

\section{PENDAHULUAN}

Masa remaja merupakan masa transisi yang unik dan ditandai oleh berbagai perubahan fisik, emosi dan psikis. Masa remaja, yaitu usia 10-19 tahun merupakan masa yang khusus dan penting, karena merupakan periode pematangan organ reproduksi manusia dan sering disebut juga masa pubertas (Anonimous, 2011).

Masalah seksualiats pada remaja merupakan masalah yang menarik perhatian semua kalangan, hal ini yang membuat masalah seksualitas selalu dibicarakan. Tentu saja masalah seksualitas menarik untuk dibahas karena menyangkut tatanilai kehidupan manusia. Selain itu, hubungan seks manusia adalah pencetus dari cinta antar individu (Chandranita, M. 2012).

Perkembangan seksualitas pada masa remaja diawali ketika terjadinya interaksi antar lawan jenis, baik itu interaksi antar teman maupun interaksi ketika berkencan. Dalam berkencan dengan pasangannya, remaja melibatkan aspek emosi yang diekspresikan dengan berbagai cara, seperti memberikan bunga, tanda mata, mengirim surat, bergandengan tangan, kissing dan sebagainya (Sarwono, W., 2011).

Salah satu dampak dari perilaku seks pranikah adalah kehamilan yang tidak diinginkan (KTD). Remaja yang mengalami hal ini, belum merasa siap secara fisik, mental dan sosial ekonomi. Sehingga calon ibu merasa tidak ingin dan tidak siap untuk hamil. Sulit 
mengharapkan adanya kasih sayang yang tulus dan kuat dalam diri calon ibu, sehingga masa depan anak bisa saja terlantar (Banun, et. al., 2012).

Remaja yang hamil di luar nikah memicu peningkatan kejadian aborsi dikalangan remaja. Angka kejadian aborsi di Indonesia tahun 2013 cukup tinggi, berkisar 2-2,6 juta kasus pertahun. Hal ini menunjukkan bahwa terjadi 43 aborsi untuk setiap 100 kehamilan. Dan dari 30\% kasus aborsi itu dilakukan oleh penduduk usia muda, antara 15-24 tahun (Anonimous, 2017). Perilaku seksual pranikah pada remaja sudah menjamur di belahan dunia, baik Negara maju maupun Negara berkembang (Jones, D., 2005).

Berdasarkan data WHO (2011) yang mencatat perilaku seksual di 27 dari 33 negaranegara Afrika, Bangladesh, India, Neval, Yaman, semua Amerika Latin dan negara Karibia, diketahui sebanyak $40 \%$ sampai $80 \%$ perempuan telah aktif dalam seksualitas pada usia 18 tahun, begitu juga di Uganda, tercatat sebanyak 4\% dari remaja laki-laki berusia 10 tahun yang mengatakan mereka sudah melakukan hubungan seksual, sebanyak $10 \%$ pada usia 12 tahun, sebanyak $22 \%$ pada usia 14 tahun, dan lebih dari $70 \%$ pada usia 18 tahun.

Fakta tersebut membuktikan bahwa kasus ini banyak terjadi di kalangan pelajar sekolah menengah sampai kalangan mahasiswa. Sehingga hal ini menjadi catatan di dalam dunia pendidikan Indonesia. Lebih gawatnya lagi, seks bebas (free sex) itu kini telah menjadi tren oleh beberapa kelompok pelajar serta merupakan bagian dari budaya yang ada di masyarakat (Fatmawati Y, 2013).

Data Badan Kependudukan dan Keluarga Berencana Nasional (BKKBN) tentang Survei Kesehatan Reproduksi Remaja Indonesia pada 2002-2003, melaporkan bahwa remaja yang mengaku memiliki teman yang pernah melakukan hubungan seksual sebelum menikah pada usia 14-19 tahun, saat itu masih ada angka 34,7\% untuk remaja putri dan 30,9\% untuk remaja putra.Sedangkan temuan terakhir sudah menunjukan peningkatan sampai menyentuh 93,7\% (Hendra, 2013).

Menurut Dianawati (2009) faktor yang memengaruhi perilaku seks pranikah adalah : adanya dorongan biologis, ketidakmampuan mengendalikan dorongan biologis, kurangnya pengetahuan tentang kesehatan reproduksi, suka sama suka, adanya kesempatan melakukan hubungan seksual, kesibukan orang tua, pemberian fasilitas (termasuk uang secara berlebihan, pergeseran nilai-nilai moral dan etika di masyarakat dan kemiskinan. Pengetahuan seks yang luas menjadikan sesorang lebih berdaya dalam memutuskan mana yang terbaik untuk kehidupan seksualitasnya. Ia akan mampu untuk menolak ajakan untuk melakukan hubungan seks pranikah (Andalia, et.al., 2017).

\section{BAHAN DAN METODE}

Penelitian yang digunakan dalam penelitian ini adalah penelitian kualitatif dengan pendekatan studi kasus. Dalam hal ini peneliti menggunakan studi kualitatif karena peneliti ingin menggali realita yang sebenarnya belum tentu tergali dengan menggunakan studi kuantitatif. Penelitian ini akan menggali apa sebenarnya faktor penyebab terjadinya perilaku seks pranikah pada remaja. Lokasi penelitian ini dilakukan di Desa Meunasah Gadong Kecamatan Kota Juang Kabupaten Bireuen Tahun 2017.

Subjek penelitian ini adalah remaja di Desa Meunasah Gadong Kecamatan Kota Juang Kabupaten Bireuen yang melakukan perilaku seks pranikah. Subjek yang diambil, dipertimbangkan dari variasi data yang ada di lapangan. Pengumpulan data dilakukan dengan wawancara mendalam (in depth-interview). Analisis data menggunakan teknik "on going analysis." 
Nurlaely HS, Fikarwin Zuska, Achmad Rifai

\section{HASIL PENELITIAN DAN PEMBAHASAN}

Perilaku seks pranikah atau seks bebas memang kasat mata, namun ia terjadi dengan sendirinya melainkan didorong atau dimotivasi oleh faktor-faktor internal yang tidak dapat diamati secara langsung (tidak kasat mata), sehingga individu tergerak untuk melakukan perilaku seks bebas. Motivasi merupakan penggerak perilaku. Motivasi tertentu akan mendorong seseorang untuk melakukan perilaku tertentu pula. Pada seorang remaja, perilaku seks bebas dapat dimotivasi oleh rasa saying dan cinta dengan didominasi oleh perasaan kedekatan dan gairah yang tinggi terhadap pasangannya, tanpa disertai komitmen yang jelas (romantic love) (Taufik, N.R., 2005).

Berdasarkan data Sexual Behavior Survey tahun 2011 yang melakukan survei di lima kota besar, yaitu Jabodetabek, Bandung, Yogyakarta, Surabaya dan Bali mendapatkan hasil bahwa para partisipan, umumnya melakukan hubungan seks bersama pacar (88\%).

Seperti halnya pada dua kasus yang diteliti, kedua remaja putri tersebut melakukan hubungan seks pranikah dengan pacarnya karena adanya tekanan atau dorongan dari pacar dengan melakukan bujuk rayu dan rangsangan-rangsangan sehingga membuat mereka tidak dapat menolak ajakan pacarnya melakukan hubungan seksual, selain adanya kesempatan membuat hubungan seks pranikah tersebut dapat terjadi. Seperti penuturan informan berikut ini.

Kejadian Pertama :

"Pacaran kami awalnya biasa saja, tidak ada yang aneh-aneh. Tapi lama kelamaan, AG semakin berani dalam berpacaran. Pada saat kejadian yang pertama kali kami berhubungan intim, awalnya AG mendekati saya, tangan saya dipegang, sambil dia berkata dengan rayuannya "dia sayang dan cinta pada saya" tak lama saya dipeluk kemudian di raba-raba dengan lembut payudara saya sampai akhirnya kami pun rebahan. Perlahan-lahan dia membuka satu persatu baju saya dan terus meraba-raba bagian sensitif saya."

(Kasus 1)

Kejadian Kedua :

"Sampai di rumah temannya ada beberapa orang di situ. Setelah $1 / 2$ jam temannya pergi satu persatu dan akhirnya kami berduaan. AG pun pelan-pelan duduk berdekatan dengan saya. Saya juga takut, saya bilang jangan, tapi lama-lama dia pun tidak bisa menahan nafsu itu. Dia bilang tidak apa-apa sedikit saja, saya pun tak kuasa menahan rayuannya juga karena saya juga rindu dan cinta sekali dengan dia."

(Kasus 1)

Kejadian Pertama :

"Suatu hari kami berduaan di tempat sepi PN mengajak saya duduk berduaan sehabis pulang nonton balap motor tak jauh jaraknya ada tempat yang sepi di dalam pepohonan hutan di situ kami rebahan berdua, sesekali PN memegang tubuh saya dan paha saya terus dia merayu saya untuk sedikit membuka baju saya. Awalnya saya keberatan tapi lama kelamaan saya tidak tahan, terus menerus PN meraba bagian-bagian sensitive saya, rasanya saya lemas dan di situlah PN buka satu persatu baju saya, dan akhirnya kami melakukan hubungan intim itu."

(Kasus 2)

Besarnya rasa cinta dan rayuan pacar untuk melakukan hubungan intim membuat remaja putri tersebut tidak berdaya menghadapinya, sampai akhirnya kedua remaja putri tersebut terbujuk dan mau melakukan hubungan seks pranikah. Rangsangan seksual dari pacar yang benar-benar dicintainya dan dibumbui dengan rayuan bahwa mereka sangat 
mencintai dan tidak akan meninggalkannya membuat remaja putri terjatuh dalam pelukan pacarnya. Gencarnya pertemuan dan setiap kali bertemu terjadi rangsangan-rangsangan pada pasangan menyebabkan banyak remaja putri takluk pada rayuan.

Terjadinya perilaku kehamilan pranikah, salah satu faktor penyebabnya karena pergaulan bebas. Seperti yang terjadi pada kasus 2 bahwa dirinya terbiasa secara bebas menonton film porno dan menggunakan narkoba maka akan berpandangan sama juga dengan perilaku seks yaitu seks bebas.

Terjadinya perilaku kehamilan pranikah, salah satu faktor penyebabnya karena pergaulan bebas. Seperti penuturan informan 2 yang sudah biasa menonton film porno dengan temannya :

"Di rumah teman biasanya sesekali saya nonton film porno, maklum teman saya orang tuanya kerja di Malaysia."

Pernyataan informan 2 tersebut menunjukkan bahwa kebiasaan menonton film porno memengaruhi pandangannya tentang perilaku seks pranikah. Dengan biasa melihat film porno maka dirinya menganggap bahwa hubungan seks adalah hal yang biasa. Kemudahan menonton film porno karena kurangnya pengawasan orang tua (orang tua bekerja di Negara lain yaitu di Malaysia) menyebabkan aktivitas mereka tidak ada yang mengontrol, sementara orang yang diserahkan tanggung jawab oleh orang tuanya yaitu abang temannya informan 2 juga sibuk berjualan sehingga tidak dapat mengawasi aktivitas adiknya di rumah.

Faktor pergaulan bebas selain menonton film porno, juga karena terbiasa mengkonsumsi zat-zat berbahaya. Seperti yang terjadi pada kasus 2 bahwa dirinya terbiasa berkumpul-kumpul dengan teman dan pacarnya, mendengar musik-musik remix, bahkan mereka juga menghisap ganja. Seperti penuturan informan 2 berikut ini :

"Ada satu teman saya dari Medan, dia suka menawari kami sejennis ganja... kawankawan pada pakek, nanti saya di bilang kampungan, tidak tahu pergaulan."

(Kasus 2)

"Waktupun berlalu dan tidak disangka rupanya cowok-cowok itu membawa ganja seperti rokok dan saya lihat PN juga, diiringi music remix kami pun bernyanyi-nyanyi sembari dia menyuruh kami untuk menghisap, itu katanya hanya sekali saja (untuk coba-coba) dan pada waktu itu kami berpasang-pasangan dengan cowok masingmasing saling berkaraoke, kami bernyanyi-nyanyi, seperti orang play kami bersenangsenang."

(Kasus 2)

Kebiasaan mengkonsumsi ganja yang dilakukan oleh teman-teman informan 2 menyebabkan dirinya juga terpengaruh untuk menghisapnya dengan alas an takut dibilang kampungan atau tidak tahu pergaulan. Informan 2 juga beralasan bahwa dia mengkonsumsinya jika dalam kondisi kacau (ada masalah).

Kebiasaan mengkonsumsi ganja (di kalangan mereka biasa menyebutnya dengan obat penenang) sebagai pelarian menjadi cara informan 2 untuk membuat dirinya merasa tenang. Hal tersebut terjadi ketika informan 2 sudah hamil dan merasa bosan dengan keadaan yang dialaminya. Dirinya mencari teman-temannya yang biasa kumpul-kumpul untuk meminta ganja. Tetapi teman-temannya menyarankan agar informan 2 tidak mengkonsumsi ganja karena dapat membuat bayinya lahir cacat. Seperti penuturan informan 2 berikut : 
Nurlaely HS, Fikarwin Zuska, Achmad Rifai

"Kehamilan saya lalui dengan hidup prihatin, kadang saya mencoba menghubungi ER, tapi susah tidak diangkat-angkat telponnya. Ada niat saya kalau lagi pusing ingin dapat obat penenang (ganja) dari teman-teman saya itu."

(Kasus 2)

“... mereka bilang saya lagi hamil jangan pakai nanti anak saya cacat.”

(Kasus 2)

Dari pernyataan informan 2 tersebut terlihat bahwa informan tidak tahu bahaya mengkonsumsi ganja terhadap kondisi janin yang dikandungnya. Informan 2 selalu berpikiran pendek bahwa untuk menghindari permasalahan hidup dapat diselesaikan dengan mengkonsumsi ganja. Tetapi untung saja teman-teman informan 2 masih dapat memberi penjelasan padanya bahwa mengkonsumsi ganja pada masa kehamilan dapat menyebabkan bayi lahir cacat sehingga dirinya hanya bergabung-gabung saja dengan teman-temannya.

Hasil wawancara dengan informan 1 dan 2, keduanya kurang mendapat kan perhatian yang cukup dari kedua orang tuanya. Mereka mendapat kasih sayang hanya dari ibunya, sedangkan ayahnya lebih banyak bekerja mencari nafkah sehingga komunikasi antara keduanya jarang.

"Selain sebagai kepala rumah tangga, Pak IY juga ditunjuk menjadi ketua RT, oleh karena menjadi seorang ketua RT, Pak IY kadang pulang larut malam karena ada urusan-urusan warga masyarakat yang harus diselesaikan, sehingga kadang jarang bertemu dengan keluarga"

(Kasus 1)

"Ayah orangnya tegas dan tidak suka banyak cerita kalau tidak perlu, dia berbicara jika ada hal-hal yang penting dan perlu saja. Jarang menanyakan keadaan sekolah saya"

(Kasus 2)

Kedua informan menyatakan bahwa orang tuanya terutama ayahnya adalah orang yang tegas dan jarang bertemu dan jarang menanyakan keadaan sekolah anakanaknya. Pada kasus 1, ayahnya seorang ketua RT yang banyak kesibukan mengurusi warganya hingga sering kali selesai sampai larut malam sehingga jarang bertemu dengan anak-anaknya. Sedangkan pada kasus 2, ayahnya adalah seorang satpam yang tegas dan tidak banyak cerita sehingga untuk komunikasi anak-anak juga jarang. Ayahnya merupakan orang yang temperamental dengan sering memukul dan menampar informan 2.

Berdasarkan hasil wawancara dengan informan bahwa mereka tidak menyadari dirinya hamil setelah melakukan hubungan seksual, informan juga kurang mendapatkan informasi seks yang benar. Seperti penuturan informan berikut :

"NL bertanya pada saya kenapa saya sakit-sakit terus, dia prihatin melihat saya. Saya menceritakan ke dia kenapa saya sering pusing, dan tidak dapat haid."

(Kasus 1)

“... saya merasa bahwa saya lemas dan pada waktu itu saya memang lagi demam dan kurang sehat tapi yang saya heran kenapa saya tidak dapat haid.”

(Kasus2)

"Kalau saya gabung sama teman-teman, di situ saya banyak tahu film-film seks, dan saya sesekali baca di buku seks, tentang hubungan wanita dan pria tapi tidak terlalu mendalam, 
Serambi Saintia

saya lebih senang melihat foto-foto seks, untuk senang-senang saja. Kalau di bangku sekolah informasi seks tidak saya dapatkan, paling hanya sepintas saja."

(Kasus 2)

Pernyataan kedua informan tersebut hampir sama tentang kehamilan yang terjadi pada dirinya. Kedua informan tidak mengerti dan kurang memahami tanda-tanda dan gejala pada wanita hamil yaitu mengalami pusing-pusing, dan tidak mendapatkan haid. Keduanya akhirnya menceritakan hal tersebut kepada teman dekatnya, dan dengan teman dekatnya tersebut mereka akhirnya membeli alatb tes kehamilan dan memeriksakan diri ke bidan. Kurangnya pengetahuan informan tentang tanda dan gejala kehamilan disebabkan mereka tidak mendapatkan informasi seks yang benar tentang hubungan seks yang dapat menyebabkan kehamilan. Seperti yang terjadi pada informan 2 yang menyatakan bahwa informasi seks diperolehnya hanya sepintas dari teman-temannya yaitu dari gambar-gambar porno yang mudah ditemui di perangkat seluler (handphone) dan media massa lainnya.

Masyarakat yang taat hukum, dalam contoh kasus ini adalah tetangga, memiliki kewajiban untuk mengawasi, mengingatkan dan melaporkan peristiwa yang tidak baik yang terjadi dilingkungan tempat dia tinggal kepada kepala desa atau ketua RT. Seperti penuturan yang disampaikan informan berikut.

"Kami (LY dan teman-teman wanitanya) suka takut kalau ada mereka (teman cowok) yang datang ke rumah untuk kumpul-kumpul. Karena tetangga di situ pernah bilang, kalau ada cowok dalam rumah kami, maka mereka akan melaporkannya pada Pak Lurah setempat. Jadi, jika kami ingin gabung atau kumpul-kumpul dengan mereka, kami keluar rumah atau keluar kampung sebelah."

Berdasarkan pernyataan informan, berarti dapat dilihat bahwa tetangga mereka mengawasi yang terjadi di lingkungan sekitar tempat mereka tinggal. Jika sudah diawasi dan dilarang oleh lingkungan sekitar saja, larangan tersebut (membawa teman cowok ke rumah untuk kumpul-kumpul tanpa pengawasan orang tua/pihak yang bertangung jawab) masih dikerjakan juga, apalagi jika masyarakat umum kurang pengawasannya terhadap lingkungan sekitar. Tidak dapat dibayangkan. Oleh karena itu di setiap desa, ada Lurah atau Ketua RT sebagai tempat pengaduan pertama, agar halhal buruk dapat terdeteksi dan dapat dicegah.

Pendidikan agama yang kurang diperoleh remaja pada saat remaja, dapat menjerumuskan remaja kedalam prilaku seksual pranikah. Apalagi, jika pendidikan agama tidak disajikan secara menarik, akan membuat remaja malas untuk mempelajari agama. Ditambah lagi jika frekuensi mempelajari atau mendapatkan pendidikan agama itu sedikit/kurang sekali, mengakibatkan keimanan para remaja goyah dan mudah terpengaruh oleh lingkungan sekitar. Seperti penuturan informan berikut.

"Terakhir kali saya mendapatkan pendidikan agama itu dari pengajian waktu SMP, itupun sesekali saja saya datang. Saya males datang ke pengajian, guru mengajinya sering menegur saya tanpa alasan yang jelas. Apalagi gurunya itu terlihat garang dan tegas, jadinya saya takut, akhirnya saya malas mengaji."

(Kasus )

Pendidikan agama harus mulai gencar diangkat dan disosialisasikan kepada khalayak luas, khususnya remaja baik dalam keluarga, sekolah, kampus, tempat ibadah 
Nurlaely HS, Fikarwin Zuska, Achmad Rifai

maupun lingkungan kerja. Agar kedepannya perilaku menyimpang tersebut dapat dicegah sedikit demi sedikit.

Dampak kehamilan pranikah pada remaja putri yang sering dialami adalah keinginan menggugurkan kandungan. Hal tersebut terungkap dari pernyataan kedua informan sebagai berikut :

"Pada saat itu pikiran saya bermacam-macam, ada rencana saya minum obat dan meminum yang bersoda-soda untuk saya bisa supaya gugur kandungan ini, ..... saya hanya diam-diam saja melakukannya. Akhirnya suatu hari saya makan tape banyak sekali...",

(Kasus 1)

“... saya pergi ke bidan untuk menggugurkan kandungan ini, tapi bidan tidak mau ... akhirnya saya ingat dan minum ramuan dari teman saya seperti; soda dan air tape ...",

(Kasus 2)

Upaya mengugurkan kandungan sering menjadi pilihan remaja putri karena mereka tidak ingin menanggung rasa malu. Jalan pintas tersebut sering menjadi pilihan utama bagi remaja putri yang hamil di luar nikah karena apabila upaya tersebut berhasil maka orang lain tidak akan tahu apa yang terjadi dengan dirinya. Perilaku seksual pranikah pada remaja putri yang diteliti memiliki dampak yaitu menikah di usia muda, dan hal tersebut juga mengindikasikan mereka tidak siap menjalani kehidupan rumah tangga sebagai suami istri. Seperti penuturan informan berikut :

"Akhirnya kedua orang tua kami mengambil kesepakatan untuk menikahkan kami di luar daerah ...

(Kasus 1)

"Saya suka bingung sendiri mengurus semuanya sendiri. Padahal umur seperti saya harusnya banyak belajar dan mencari pengalaman untuk bekerja, kini baru saya rasakan betapa bodohnya saya mau secepat ini untuk berumah tangga",

(Kasus 1)

"Malam itu sekitar 23.00 malam akhirnya keluarga ambil keputusan kami akan dinikahkan secepatnya.",

(Kasus 2)

"Lama-lama saya takut rumah tangga saya tak bakal bisa sampai tua kalau tingkah PN seperti ini terus."

(Kasus 2)

Kehamilan di luar nikah berdampak pada perkawinan yang terpaksa atau belum waktunya. Dengan usia yang muda, sering membuat mereka juga tidak siap untuk menjalani kehidupan rumah tangga serta merancang masa depan.

Seperti yang dialami oleh informan 1 bahwa dirinya akhirnya menyadari bahwa tindakan perilaku seks pranikah membuatnya menjadi merasa bodoh telah menjalani kehiupan rumah tangga pada usia yang masih sangat muda. Sementara informan 2 merasa bahwa menjalani kehidupan rumah tangga pada usia muda sangat sulit apalagi keduanya masih senang kumpul-kumpul dengan temannya, sering mengambil keputusan tanpa pertimbangan yang matang. Informan 2 menyatakan bahwa suaminya sifatnya seperti kekanak-kanakan, serta egois. Dalam usia muda keduanya masih labil sehingga untuk pengambilan keputusan-keputusan penting dalam keluarga masih sering dilandasi oleh emosi. 
Serambi Saintia

Dampak kehamilan pranikah pada remaja putri menyebabkan mereka harus putus sekolah. Berikut penuturan mereka :

"Setelah kejadian itu pun saya tidak lagi pergi ke sekolah untuk melanjutkan SMK."

(Kasus 1)

"Kadang kalau teringat teman-teman saya, saya suka iri melihat mereka yang masih sekolah dan melanjutkan ke tingkat yang lebih tinggi lagi.",

(Kasus 1)

"Setelah kejadian itu saya jarang keluar rumah, disini saya mulai tidak masuk sekolah lagi.",

(Kasus 2)

Menikah di usia muda jelas membuat wanita harus rela mengorbankan pendidikan yang sebenarnya masih mampu diraihnya pada usianya kini. Tanggung jawab yang besar kemudian membuatnya mengorbankan apa yang selama ini menjadi harapan atau citacitanya di masa mendatang yang dapat ditempuh melalui jalur pendidikan. Tetapi lebih banyak remaja putri yang hamil di luar nikah memilih memutuskan untuk tidak meneruskan pendidikan karena rasa malu.

Salah satu dampak berat yang dipikul oleh remaja putri adalah diusir dari rumah karena orang tua merasa malu dan tidak mau memiliki anak seperti mereka. Seperti penuturan mereka :

“... orang tua kami mengambil kesepakatan untuk menikahkan kami di luar daerah ... kami harus pergi jauh dari desa kami karena karena orang tua merasa malu ...'

(Kasus 2)

"Setelah kami menikah, bapak dan ibu PN menyuruh kami pergi jauh dari desa.'

(Kasus 2)

Mengalami kehamilan pada masa remaja, bagaimana pun pasti menimbulkan konsekuensi yang sulit, tidak saja bagi remaja yang bersangkutan, tetapi juga bagi seluruh anggota keluarga yang lain. Remaja putri yang terlanjur hamil di luar nikah itu dalam tatanan masyarakat kita ditanyakan sebagai tindakan yang sangat memalukan keluarga, bahkan memalukan masyarakat sebagai sebuah komunitas.

Menjalani pernikahan di usia muda sebagai akibat kehamilan pranikah juga akan berdampak pula pada kesulitan ekonomi keluarga baru tersebut. Seperti penuturan informan berikut :

“Walaupun gaji AG pas-pasan saya cukup-cukupin untuk kebutuhan sehari-hari."

“Untuk makan sehari-hari saja saya pas-pasan ..."

Keputusan untuk melangsungkan pernikahan di usia muda yang bertujuan menyelesaikan masalah pasti tidak akan lepas dari kemelut atau permasalahan hidup seperti penghasilan yang terbatas atau mereka belum mampu mandiri dalam membiayai keluarga baru, bagaimana mengatur keuangan keluarga untuk berbagai keperluan seperti keperluan bayi dan kebutuhan hidup sehari-hari. Masalah ekonomi merupakan masalah yang penting dalam membina sebuah keluarga. Seringkali rumah tangga hancur dan terjadinya perceraian gara-gara ekonomi yang tidak stabil. 
Nurlaely HS, Fikarwin Zuska, Achmad Rifai

Secara ekonomi, kehidupan Dampak negatif yang sering terjadi dalam perkawinan karena masalah ekonomi yaitu terjadinya pertengkaran atau percekcokan yang berakhir perceraian, tetapi dampak positif yang mungkin juga bisa terjadi yaitu makin mengeratkan cinta mereka karena akan berjuang bersama-sama menjalani kehidupan dengan kondisi ekonomi yang seadanya.

\section{SIMPULAN}

Terdapat tiga faktor yang sama pada kasus 1 dan 2 yang mempengaruhi terjadinya kehamilan pranikah yaitu : adanya tekanan dari pacar, kurang perhatian keluarga dan kurang pengetahuan tentang kesehatan reproduksi. Jadi dari hasil penelitian yang peneliti lakukan, dapat disimpulkan bahwa ke-3 faktor inilah yang sangat berpengaruh terhadap terjadinya kehamilan pranikah. Dampak kehamilan pranikah pada remaja putri yaitu keinginan menggugurkan kandungan, menikah di usia muda dan ketidakpastian menjalani kehidupan rumah tangga, putus sekolah, diusir dari rumah, dan mengalami kesulitan ekonomi setelah menikah.

\section{DAFTAR PUSTAKA}

Andalia, N., Agnes, dan M. Ridhwan, 2017. Hubungan antara Pengetahuan dengan Persepsi Siswa terhadap Penularan Penyakit AIDs. http://www.ojs.serambimekkah.ac.id/index.php/serambi-ilmu/article/view/233

Anonimous, 2011. Yang Perlu Di Diketahui Petugas Kesehatan Reproduksi Remaja Jakarta: Kemenkes RI Direktoriat Jedral Bida Gizi dan KIA

Anonimous, 2017. Yang Muda Harus Berencana. Tribunnews.com.

Banun F, Soedijono S, 2012. Faktor-Faktor Yang Berhubungan Dengan Perilaku Seksual Pranikah Pada Mahasiswa Semester V StiKes X. Jurnal Umum Kesehatan. Jakarta Timur.

Chandranita, M. 2012. Memahami Kesehatan Reproduksi Wanita. Jakarta: EGC. Fatmawati Y, 2013. Pengetahuan Seksualitas untuk Remaja Bekasi: Nusa Agung. Hendra, 2013. Remaja dan Seks Bebas. http://www.hendra.com Jones, D., 2005. Setiap Wanita. Jakarta: Delapratasa Publishing. Sarwono, W., 2011. Psikologi Remaja Jakarta: Grafindo Persada

Taufik NR., 2005. Seksualitas Remaja Perbedaan Seksualitas antara Remaja yang tidak Melakukan Hubungan Seksualitas \& Remaja yang melakukan Hubungan Seksual.

WHO., 2011. The Sexsual and Reproductive Health of Young Research Issues in Develoving Coutries. 